\title{
Correction to: The development of delinquency during adolescence: a comparison of missing data techniques revisited
}

\author{
Kristian Kleinke $^{1}$ (D) Jost Reinecke ${ }^{2} \cdot$ Cornelia Weins $^{3}$
}

Published online: 19 August 2021

(C) The Author(s) 2021

\section{Correction to: Quality \& Quantity (2021) 55:877-895 https://doi.org/10.1007/s11135-020-01030-5}

The article "The development of delinquency during adolescence: a comparison of missing data techniques revisited", written by "Kristian Kleinke, Jost Reinecke and Cornelia Weins", was originally published Online First without Open Access. After publication in volume 55, issue 3, page 877-895 the author decided to opt for Open Choice and to make the article an Open Access publication. Therefore, the copyright of the article has been changed to () The Author(s) 2021 and the article is forthwith distributed under a Creative Commons Attribution 4.0 International License, which permits use, sharing, adaptation, distribution and reproduction in any medium or format, as long as you give appropriate credit to the original author(s) and the source, provide a link to the Creative Commons licence, and indicate if changes were made. The images or other third party material in this article are included in the article's Creative Commons licence, unless indicated otherwise in a credit line to the material. If material is not included in the article's Creative Commons licence and your intended use is not permitted by statutory regulation or exceeds the permitted use, you will need to obtain permission directly from the copyright holder. To view a copy of this licence, visit https://creativecommons.org/licenses/by/4.0. The original article has been corrected.

The original article can be found online at https://doi.org/10.1007/s11135-020-01030-5.

Kristian Kleinke

kristian.kleinke@uni-siegen.de

Jost Reinecke

jost.reinecke@uni-bielefeld.de

Cornelia Weins

cornelia.weins@rub.de

1 Department of Education Studies and Psychology, University of Siegen, Adolf-Reichwein-Str. 2a, 57068 Siegen, Germany

2 Faculty of Sociology, University of Bielefeld, 33501 Bielefeld, Germany

3 Faculty of Social Sciences, Ruhr-University Bochum, 44801 Bochum, Germany 
Open Access This article is licensed under a Creative Commons Attribution 4.0 International License, which permits use, sharing, adaptation, distribution and reproduction in any medium or format, as long as you give appropriate credit to the original author(s) and the source, provide a link to the Creative Commons licence, and indicate if changes were made. The images or other third party material in this article are included in the article's Creative Commons licence, unless indicated otherwise in a credit line to the material. If material is not included in the article's Creative Commons licence and your intended use is not permitted by statutory regulation or exceeds the permitted use, you will need to obtain permission directly from the copyright holder. To view a copy of this licence, visit http://creativecommons.org/licenses/by/4.0/.

Publisher's Note Springer Nature remains neutral with regard to jurisdictional claims in published maps and institutional affiliations. 